\title{
A retrospective study on ectopic pregnancy at tertiary care hospital: a two-year study
}

\author{
Sonal Agrawal ${ }^{1 *}$, Vimal K. Agarwal ${ }^{2}$
}

\begin{abstract}
${ }^{1}$ Department of Obstetrics and Gynecology, Jhalawar Medical College, Jhalawar, Rajasthan, India
${ }^{2}$ Department of Surgery, Balaji Hospital, Jhalawar, Rajasthan, India
\end{abstract}

Received: 28 November 2018

Accepted: 04 December 2018

\author{
*Correspondence: \\ Dr. Sonal Agrawal, \\ E-mail: drvimal01@gmail.com
}

Copyright: (c) the author(s), publisher and licensee Medip Academy. This is an open-access article distributed under the terms of the Creative Commons Attribution Non-Commercial License, which permits unrestricted non-commercial use, distribution, and reproduction in any medium, provided the original work is properly cited.

\section{ABSTRACT}

Background: Over the last few decades, the incidence of ectopic pregnancy has increased almost to extent of an epidemic disease. The rate of ectopic pregnancy has increased from $0.5 \%$ in 1970 to $2 \%$ today. The aim of this study was to determine incidence, clinical presentation, risk factor, treatment, morbidity and mortality associated with ectopic pregnancy.

Methods: The present retrospective study was conducted over a period of 2 year in department of obstetrics and gynaecology, JMCH, Jhalawar from Jan 2015 to Dec 2017. A total of 64 patients with ectopic pregnancy were analyzed.

Results: Total 64 cases of ectopic pregnancy were admitted in this duration and total no. deliveries in these 2 year was 18176 . So, incidence of ectopic pregnancy at our institute is $0.35 \%$. Most common presenting complain was pain abdomen (in $93.75 \%$ ) cases. Classical triad of pain, amenorrhea and bleeding was present in $48.3 \%$ cases.

Conclusions: Early diagnosis and timely intervention in the form of medical treatment or conservative surgery not only reduces maternal morbidity but also preserves future fertility.

Keywords: Ectopic pregnancy, Implantation, Tubal rupture

\section{INTRODUCTION}

Ectopic pregnancy is a global problem and is most common life-threatening emergency in early pregnancy leading to significant mortality and fetal loss. Blastocyst normally implants in endometrial lining of uterine cavity. Implantation anywhere else is considered as ectopic pregnancy ${ }^{1}$. Nearly $95 \%$ of ectopic pregnancies are implanted in various segments of the fallopian tubes.

Of these most common are ampullary implantations. The remaining $5 \%$ implants in ovary, peritoneal cavity or within cervix. Prior tubal damage either from previous ectopic pregnancy or from tubal surgery to relieve infertility or for sterilization confers highest risk for ectopic pregnancy. Infertility per se as well as use of ART to overcome it is associated with increased risk of ectopic pregnancy. Salpingitis, prior tubal infection or STD, postabortal or puerperal infection, smoking, multiple sexual partners are other risk factors for ectopic pregnancy ${ }^{1}$. Chlamydia trachomatis has been linked to $30-50 \%$ of all ectopic pregnancies ${ }^{2}$. Ectopic pregnancy is a challenge to obstetrician due to its bizarre clinical presentation.

Diagnosis requires a high index of suspicion as the classic triad of amenorrhea, abdominal pain and vaginal bleeding is not seen in all cases.

Women may present with nonspecific symptoms, unaware of an ongoing pregnancy or may even present with hemodynamic shock. Early diagnosis reduces risk of tubal rupture and allows more conservative and medical treatment to be employed ${ }^{3}$. 


\section{METHODS}

This retrospective study was conducted in department of Obstetrics and Gynecology at JMCH, Jhalawar over a period of 2 years from Jan 2016 to Dec 2017.

The case sheets of the patients with ectopic pregnancy were traced through the labour ward registers and operation theatre registers. Records were studied for demographic characteristics, period of amenorrhea, at time of diagnosis, presenting complains like pain abdomen and bleeding per vagina.

Predisposing high risk factors were also analyzed. A documentation of UPT was done, USG findings were noted down. Important intra operative findings were also noted down. All the information was entered in a prestructured proforma. All the data were analyzed by percentage method.

\section{Inclusion criteria}

- All women with confirmed ectopic pregnancy.

\section{RESULTS}

During study period of 2 year, the total no. of deliveries in our hospital was 18176 and 64 cases were diagnosed as ectopic pregnancy. So, incidence of ectopic pregnancy is $0.35 \%$. Age ranged from $18-35$ years. Majority of patient belonged to age group 20-30-year (73.43\%) Table 1. In present study, $77 \%$ of patients were multigravida and $16 \%$ patient were primigravida and $7 \%$ patients were nullipara. Most of cases were diagnosed at gestational age of 6-8 weeks. (65.62\%) (Figure 1).

Table 1: Distribution of age.

\begin{tabular}{|l|l|l|}
\hline Age & No. & Percentage \\
\hline$<20$ & 6 & 9.37 \\
\hline $21-25$ & 30 & 46.87 \\
\hline $26-30$ & 17 & 26.56 \\
\hline$>30$ & 11 & 17.18 \\
\hline
\end{tabular}

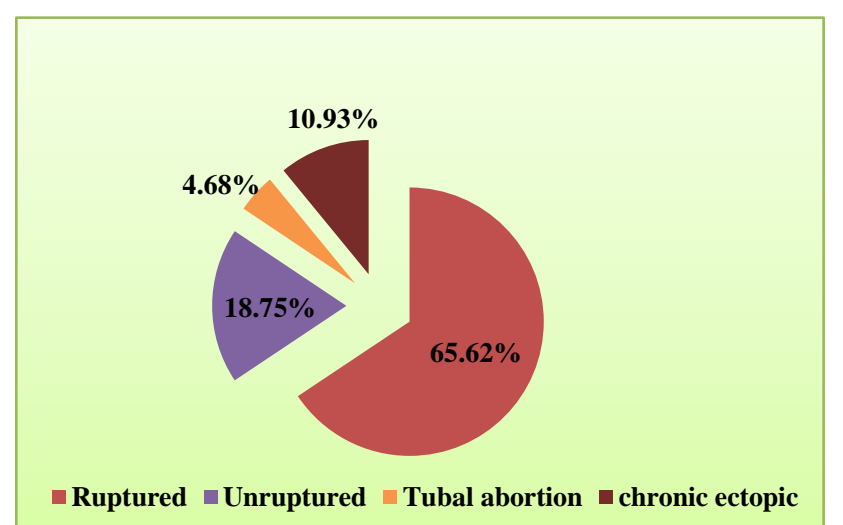

Figure 1: Distribution of cases according to per operative findings.
$35.93 \%$ patient had no risk factors. $29.68 \%$ patient has history of PID. $10.93 \%$ patient has history of previous tubal surgery. $9.37 \%$ patient has history of previous ectopic pregnancy and $6.25 \%$ patient had history of IUCD insertion (Table 2).

Table 2: Risk factors.

\begin{tabular}{|l|l|l|}
\hline Risk Factors & No. & Percentage \\
\hline H/o PID & 19 & 29.68 \\
\hline H/o previous ectopic & 6 & 9.37 \\
\hline H/o IUCD insertion & 4 & 6.25 \\
\hline H/o tubal surgery & 7 & 10.93 \\
\hline Infertility & 5 & 7.81 \\
\hline
\end{tabular}

Most common presenting complain was pain abdomen $(93.75 \%)$ followed by amenorrhea $(82.81 \%)$, bleeding per vagina was present in $51.56 \%$ cases, sign of adenexal tenderness was present in $65.62 \%$ cases. $28.12 \%$ patients presented with shock. Triad of pain, amenorrhea and bleeding per vagina was present in $48.43 \%$ cases (Table $3)$.

Table 3: Clinical features at presentation.

\begin{tabular}{|l|l|l|}
\hline Clinical features & No. & Percentage \\
\hline Abdominal pain & 60 & 93.75 \\
\hline Vaginal bleeding & 33 & 51.56 \\
\hline Cervical tenderness & 30 & 46.87 \\
\hline Adenexal tenderness & 42 & 65.62 \\
\hline Shock & 18 & 28.12 \\
\hline
\end{tabular}

Most common site of tubal pregnancy was ampullary (48.43\%) followed by isthmic $(12.5 \%)$. There was only one case of ovarian pregnancy and one case of secondary abdominal pregnancy (Figure 2).

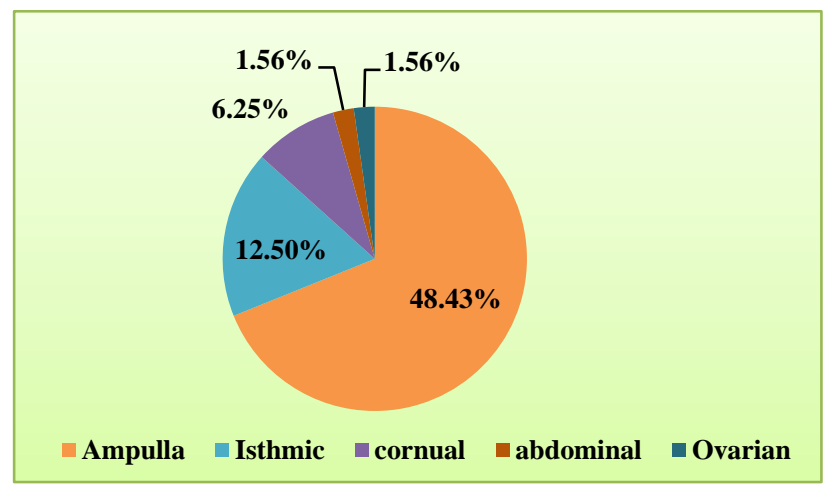

Figure 2: Sites of ectopic pregnancy in patient who underwent surgery.

Ruptured ectopic pregnancy was present in $65.62 \%$ case, unruptured in $18.75 \%$, tubal abortion in $4.68 \%$ and chronic ectopic in $10.93 \%$ cases. Fig.3. Laparotomy followed by salpingectomy was mainstay of treatment $(79.68 \%)$. Salpingo oophorectomy was performed in $9.37 \%$ cases. Salpingectomy along with contralateral tubectomy was performed in $17.1 \%$ cases as their family 
was complete. $90 \%$ patient had blood transfusion. There was no maternal death in present study.

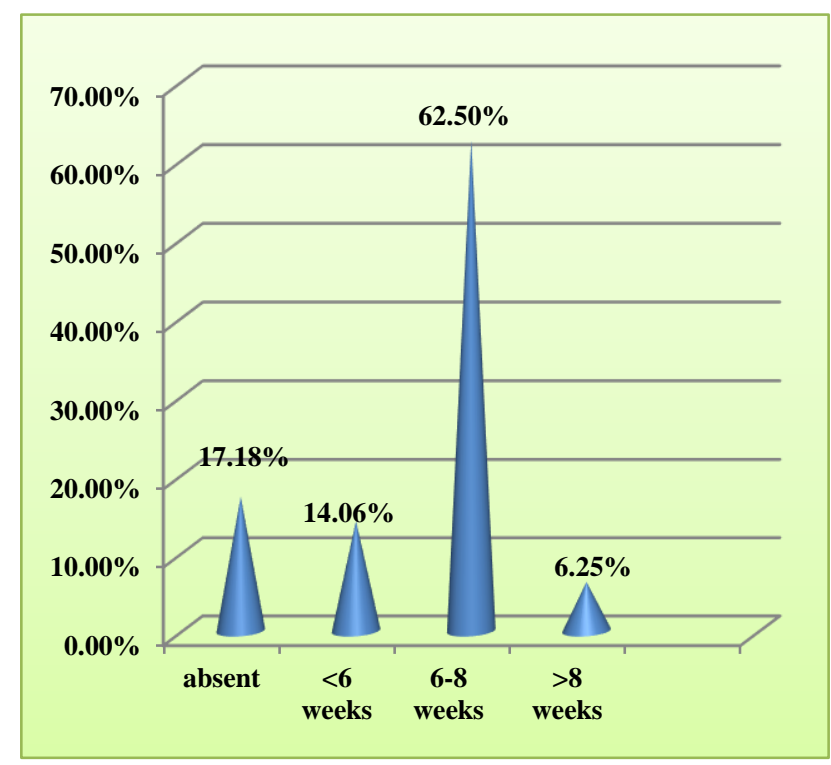

Figure 3: Distribution according to duration of amenorrhea.

\section{DISCUSSION}

Ectopic pregnancy is an increasingly common and potentially catastrophic condition. The prevalence of ectopic pregnancy among women who present to emergency department with 1 st trimester bleeding or pain or both varies from 6 to $16 \%{ }^{4}$. It remains as an important contributor to maternal mortality and morbidity and is one of commonest cause of 1 st trimester maternal deaths. It accounts for $3.5 \%-7.1 \%$ of maternal mortality in India. ${ }^{5,6}$ In present study incidence of ectopic pregnancy majority of cases belong to age group 21-25 year. This is similar to study by Rakhi et al in which peak age incidence was 20-25 years ${ }^{7}$. In ICMR multicentric case control study of ectopic pregnancy majority of patient were young. ${ }^{4}$

In present study history revealed presence of at least one high risk factor in $64.07 \%$ cases. History of PID was present in $29.68 \%$ patient. This is correlating with study done by Bhavna et al who reported history of PID in $22.7 \%$ cases with ectopic pregnancy. ${ }^{8}$

In present study $7.81 \%$ patients were infertile which is similar to Samiya Mufti et al $(8.77 \%)$ and Panchal D et al (11.66\%). ${ }^{9,10}$ Association between infertility and previous pelvic infection and tubal pathology is possible explanation.

In present study 9.37 percent patients had history of previous ectopic pregnancy. Recurrence of ectopic has been reported in various studies, ranging between 3.2\%$20 \%$. So, such patients need to be educated about risk of recurrences. Significant incidence of prolonged infertility and its casual relationship to ectopic pregnancy has been observed by various authors.

In present study $93.75 \%$ patients had pain abdomen, $51.56 \%$ patient had vaginal bleeding, $46.87 \%$ had cervical tenderness, $62.62 \%$ cases had adenexal tenderness. Shock was present in $28.12 \%$ cases. $82.81 \%$ patient had amenorrhea. In a study by AO Igwegbe et al majority $(80.61 \%)$ patient presented with abdominal pain and $35.8 \%$ presented with vaginal bleeding. ${ }^{11}$ In the study by Shiv Kumar $\mathrm{HC}$ et al, $95 \%$ patient had pain abdomen, $80 \%$ had amenorrhea, $70 \%$ had bleeding P/v, 30\% had vomiting and $5 \%$ had urinary complains. ${ }^{12,13}$ In study by Shah $\mathrm{N}$ et al, the most common presenting symptoms was abdominal pain $(97.31 \%)$ whereas history of amenorrhea and vaginal bleeding was found in $73.6 \%$ and $57.81 \%$ patient respectively. ${ }^{13}$

In present study ruptured ectopic pregnancy was seen in $65.62 \%$ patient similar to results of Shetty et al who reported cases of ruptured ectopic as $61.3 \% .{ }^{4}$ In present study $18.75 \%$ patient had unexplained ectopic which is correlating with study of Gaddagi RA et al $(8.1 \%) .{ }^{14}$

In present study ampulla was MC site of ectopic pregnancy $(48.43 \%)$ followed by isthmus (12.5\%). Cornual pregnancy was present in (6.25\%) cases, abdominal in $(1.56 \%)$ and ovarian in $1.56 \%$ cases. These are comparable to study by Bouyer et al who suggested sites of ectopic pregnancy as ampullary (70\%), isthmic $(12 \%)$, interstitial $(2.4 \%)$, ovarian $(3.2 \%)$ and abdominal $(1.3 \%) .^{15}$

Laparotomy followed by salpingectomy was most common modality of treatment $(79.68 \%)$ cases which is similar to Shetty et al $(90.3 \%)$ and Majhi et al $(81.9 \%)$. There was no mortality in present study. 4,16

Funding: No funding sources

Conflict of interest: None declared

Ethical approval: The study was approved by the Institutional Ethics Committee

\section{REFERENCES}

1. Cunningham F, Leveno K, Bloom S, Hauth J, Rouse D, Spong C. Williams Obstetrics 23rd Edition McGraw Hill. New York. 2010:2010.

2. Turner C, Horner P. British Fertility Society Guidelines for practice. Hum Fertil (Camb). 2010;13(3):115-25.

3. Barnhart KT, Clinical practice, Ectopic pregnancy, N Engl J Med. 2009;361(4):379-87.

4. Shetty S, Shetty A. A clinical study of ectopic pregnancies in a tertiary care hospital of Manglore, India. Innov J Med Health Sci. 2014;4(1).

5. Shah P, Shah S, Kutty RV, Modi D. Changing epidemiology of maternal mortality in rural India: time to reset strategies for MDG-5. Trop Med Int Health. 2014;19(5):568-75. 
6. Yadav K, Namdeo A, bhargava M. a retrospective and prospective study of maternal mortality in a rural tertiary care hospital of Central India. Indian $\mathbf{J}$ Comm Health. 2013;25(1):16-21.

7. Rakhi MP, Nupur H, Agarwal A, Makkar P, Fatima A. Ectopic pregnancy: a devastating catastrophe. SCH J App Med Sci. 2014;2(3A):903-7.

8. Gupta BK, Pathania BK, Jindal M, Vohra R, Ahmed M. Risk Factors for ectopic pregnancy, a case control study in tertiary care centre, journal of Dental and Med Sc. 2014;13(3):23-7.

9. Shagufta SM, Samina M, Reyaz AR, Wasiqa K. Ectopic pregnancy, an analysis of 114 cases. JKPract. 2012;17(4):20-3.

10. Panchal D, Vaishanav G, Solanki K. Study of Management in patient with ectopic pregnancy. Nat J Integ Res Med. 2011;2(3):91-4.

11. Igwegwe AO, Eleje GU, okpala BC. An appraisal of the management of ectopic pregnancy in a Nigerian tertiary hospital. Ann Med Health Sci Res.2013;3(2):166-70.

12. Shivkumar HC, Umashankar KM, Ramaraju HE. Analysis of forty cases of ectopic pregnancies in tertiary care hospital in South India. Indian J Basic Appl Med Res.2013;3(1):235-41.

13. Shah $\mathrm{n}$, khan $\mathrm{NH}$, ectopic pregnancy: presentation and risk factors. J Coll Physicians Surg Pak 2005;15(9):535-8.

14. Gaddagi RA, Chandrashekhar AP. A clinical study of Ectopic Pregnancy. J Clinic Diag Res. 2012;6(5):867-9.

15. Maymon R, Shulman A, Maymon B, Bar-levy F, Lotan M, Bahary C. Ectopic pregnancy, the new gynaecological epidemic disease: review of the modern work up and the non-surgical treatment option. Int J fertile. 1992:37(3):146-64.

16. Majhi AK, Roy N, Karmakar KS, Banarjee PK. Ectopic pregnancy: an analysis of 180 cases. J Indian Med Assoc. 2007;105(6):308-10.

Cite this article as: Agrawal S, Agarwal VK. A retrospective study on ectopic pregnancy at tertiary care hospital: a two-year study. Int J Reprod Contracept Obstet Gynecol 2019;8:50-3. 